\title{
Invasion of Nostocales (cyanobacteria) to subtropical and temperate freshwater lakes - physiological, regional, and global driving forces
}

\author{
Assaf Sukenik ${ }^{1}$, Ora Hadas ${ }^{1}$, Aaron Kaplan² and Antonio Quesada ${ }^{3}$ \\ 1 The Yigal Allon Kinneret Limnological Laboratory, Israel Oceanographic and Limnological Research, Migdal, Israel \\ 2 Department of Plant and Environmental Sciences, The Hebrew University, Jerusalem, Israel \\ ${ }^{3}$ Departamento de Biología, Universidad Autónoma de Madrid, Madrid, Spain
}

\section{Edited by:}

Anton F. Post, H. Steinitz Marine

Biology Laboratory, USA

\section{Reviewed by:}

Robert M. McKay, Bowling Green State University, USA

Rachael Marie Morgan-Kiss, Miami University, USA

*Correspondence:

Assaf Sukenik, The Yigal Allon

Kinneret Limnological Laboratory, Israel Oceanographic and

Limnological Research, P.O. Box 447,

Migdal 14950, Israel.

e-mail: assaf@ocean.org.il

\begin{abstract}
Similar to the increased number of studies on invasive plants and animals in terrestrial and aquatic ecosystems, many reports were recently published on the invasion of Nostocales (cyanobacteria) to freshwater environments worldwide. Invasion and proliferation of Nostocales in new habitats have the potential to significantly alter the structure of the native community and to modify ecosystem functioning. But most importantly, they influence the water quality due to a variety of toxic compounds that some species produce. Therefore a special attention was given to the invasion and persistence of toxic cyanobacteria in many aquatic ecosystems. Here we summarize the currently published records on the invasion of two Nostocales genera, Cylindrospermopsis and Aphanizomenon, to lakes and water reservoirs in subtropical and temperate zones. These invading species possess traits thought to be common to many invasive organisms: high growth rate, high resource utilization efficiency and overall superior competitive abilities over native species when local conditions vary. Assuming that dispersion routes of cyanobacteria have not been changed much in recent decades, their recent establishment and proliferation in new habitats indicate changes in the environment under which they can exploit their physiological advantage over the native phytoplankton population. In many cases, global warming was identified as the major driving force for the invasion of Nostocales. Due to this uncontrollable trend, invasive Nostocales species are expected to maintain their presence in new habitats and further expand to new environments. In other cases, regional changes in nutrient loads and in biotic conditions were attributed to the invasion events.
\end{abstract}

Keywords: cyanobacteria, Nostocales, Cylindrospermopsis, Aphanizomenon, invasive species, climate change, eutrophication

\section{INTRODUCTION}

The entry, establishment, and spread of non - native species to a new ecosystem, is frequently described as biological invasion (Vitousek et al., 1997; Ricciardi and Cohen, 2007). In many cases, biological invasions are caused by human - induced environmental interference and have substantial economic impact, serious ecological consequences, and human health hazards (Pimentel et al., 2001). They also may threaten global biodiversity by altering the structure and function of ecosystems and disrupting key biological interactions (Levine et al., 2003; Traveset and Richardson, 2006). The invasion of freshwater and marine ecosystems by non-native species of various taxonomic groups, mostly crustaceans, mussels, fish, and aquatic macrophytes is well documented (Meinesz et al., 2001; Richardson, 2011). The invasion of free-living microorganisms to new aquatic habitats is rather cryptic and difficult to detect therefore invasions of these "invisible invaders" have been rarely reported (Litchman, 2010). Furthermore, information on prior and current composition of the microbial communities, which is required to determine if a given microorganism is an invader, is often missing. Algae and cyanobacteria are exceptions in that sense as they have visible characteristic of spectral signature and microscopic morphological features. This property partly contributed to the increased number of reports on cyanobacteria invasion to lakes and water reservoirs across Europe, North, and South America and the Middle East that were recently published (Dyble et al., 2002; Wiedner et al., 2007; Hadas et al., submitted).

Here we summarize recently published records on the invasion of cyanobacteria to subtropical and temperate lakes and water reservoirs and try to forecast different scenarios of ecological and management consequences. The invasion of two Nostocales genera, Cylindrospermopsis and Aphanizomenon is presented and analyzed based on the main concepts of invasion ecology. The following issues are critically addressed: recent variations in geographic distribution of invasive Nostocales; How does a Nostocales species become an invader? What are the special traits of the invading Nostocales? What are the level and the role of genetic variability in the invasion of Nostocales? Is invasion of Nostocales to new location further expected and under what conditions? What are the expected ecological effects of the invasion? 


\section{THE CONCEPT OF INVADING CYANOBACTERIA}

Biological invasion is considered as an extension of normal colonization processes such as succession (Elton, 1958) therefore it was proposed that the term "invasive species" will be restricted to describe non-native species that expanded their geographic range, became abundant and have environmental and economic impact (Colautti and Macisaac, 2004). Because the terminology associated with biological invasion is rather confusing and sometimes misleading (Colautti and Macisaac, 2004), here we define an invading or a non-native species as a species that spreads beyond its native range or a species that enters a habitat where it had not resided before. However, it should be kept in mind that many cyanobacteria species (as well as other microorganisms) can inhabit an aquatic ecosystem unnoticed, since it may remain at a rather low biomass concentration and it does not form a conspicuous fraction of the community. Furthermore, the lack of detailed water quality monitoring program or an insufficiently comprehensive surveillance do not pick up the presence of these species (Kling et al., 2011). Typically it is only when a non-native population is widespread and abundant, and causes ecological or economic harms, that it is named "invasive." It is possible for a species to be invasive in one ecosystem, but non-invasive in another. This can be due to a variety of factors, such as the presence of less-than-ideal habitat conditions (Lockwood et al., 2007). We further suggest evaluating the invasion of free-living microorganisms within an appropriate timeframe, since an invader may become a common resident of a dynamically changing environment. Therefore native and non-native species may be viewed as part of a continuum with respect to their time of residency and the extent of evolutionary and ecological interactions they have within a given environment.

\section{THE GLOBAL EXPANSION OF NOSTOCALES}

During the last decades, the number of reports on cyanobacterial domination and persistence in freshwater and marine ecosystems significantly increased covering spatial and temporal distribution of persistent perennial blooms. Many of these bloom events are of toxic Microcystis species and strains that proliferate under current environmental alterations, including nutrient enrichment, global warming, and regional hydrologic changes (Paerl and Paul, 2011). However, not all blooms are associated with an invasion process as many species are of broad geographic distribution and rapidly respond to current environmental changes.

The most important freshwater invasive Nostocales are the tropical species C. raciborskii and to a lesser extent also Aph. ovalisporum. The map in Figure 1 shows the current global distribution of C. raciborskii and Aph. ovalisporum in their native tropical region and in subtropical and temperate areas to which they expanded in the last two decades. C. raciborskii is a tropical species which was first described from Indonesia (Java) and was subsequently discovered in India and Thailand, Japan, the Philippines, Egypt, Senegal, Brazil, Cuba, Chile, Uruguay, Australia, New Zealand, and Florida (Bouvy et al., 2000; Molica et al., 2002; Dobberfuhl, 2003; Komárek and Komárkova, 2003; Wood and Stirling, 2003; Briand et al., 2004; Chonudomkul et al., 2004; Vidal and Kruk, 2008). Recently Kaštovský et al. (2011) summarized the invasion of freshwater cyanobacteria and algae to aquatic ecosystems in the Czech Republic and portrayed the invasion of $C$. raciborskii from its native tropical area to subtropical and temperate zones. The expansion of C. raciborskii and Aph. ovalisporum to new geographic regions is described below.

\section{CENTRAL EUROPE (GERMANY, FRANCE) AND THE IBERIAN PENINSULA}

The invasion of cyanobacteria strains in Central Europe as high biomass of the typically tropical species $C$. raciborskii was first reported in the 1970s (Romo and Miracle, 1994; Padisák, 1997). Long term phytoplankton records in some European lakes demonstrate a clear increase of some cyanobacterial species that had been absent or overlooked before (Padisák, 1997). Although C.

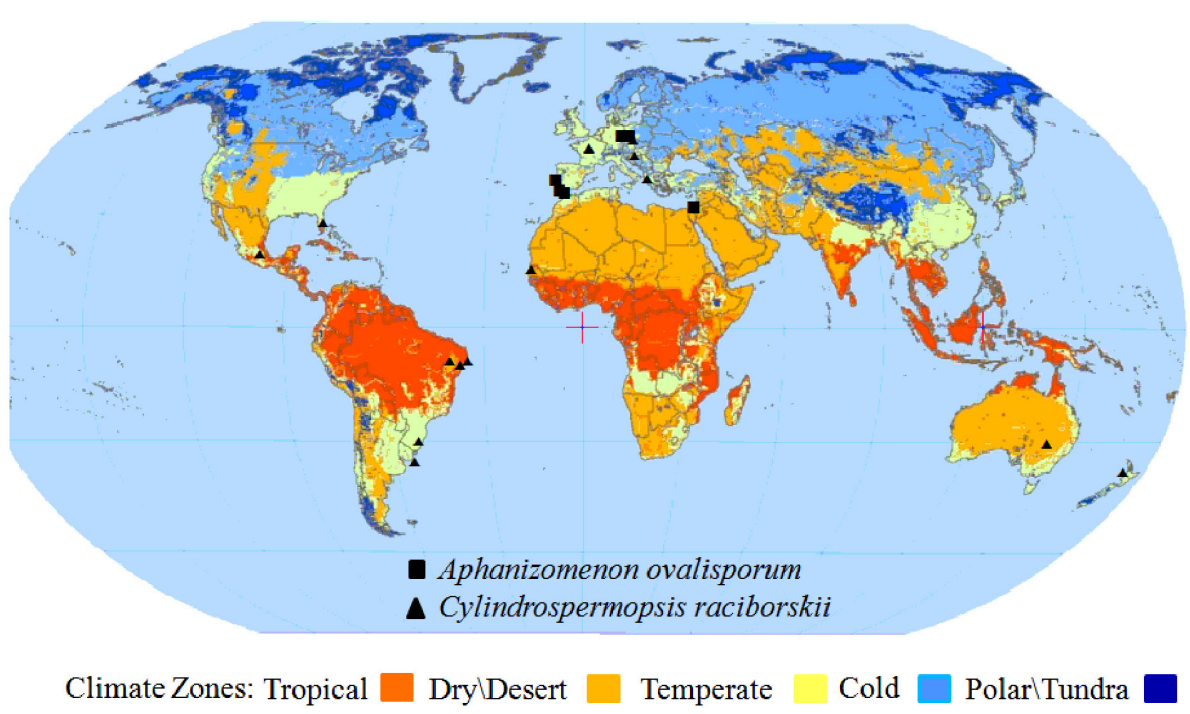

FIGURE 1 |The expansion of the Nostocales Cylindrospermopsis raciborskii (triangles) and Aphanizomenon ovalisporum (squares) to temperate and subtropical regions shown in a world climate zones map. (Map source: http://sedac.ciesin.columbia.edu/place/mapCollection/Climate_Zone). 
raciborskii was known in Europe since the 1930s, it was marginal to the southern European countries (e.g., Greece; see references in Mehnert et al., 2010). However, in the last two decades, this species has appeared in northern European regions and is currently widespread at central latitudes (Kokociński et al., 2009). Other Nostocales such as Aph. aphanizomenoides (currently designated as Sphaerospermum) and Aph. ovalisporum, are also considered invasive species in Europe and have been reported at some locations as newcomers. Aph. ovalisporum is especially relevant because it is known to produce cylindrospermopsin, although several nontoxic strains were reported (Ballot et al., 2011). Aph. ovalisporum was described in different ecosystems of southern Europe (Bazzichelli and Abdelahad, 1994) and in the Iberian Peninsula where it produced massive blooms for the first time in 2005 (Quesada et al., 2006). Later, it has been found at least in seven water bodies in central Spain (Cirés, 2012) and in several water bodies in the southern areas of the country (C. de Hoyos, Personal Communication). Aph. ovalisporum has been found in the Iberian Peninsula, both in deep stratified reservoirs and in very shallow (less than $1 \mathrm{~m}$ ) ponds of urban gardens. The spread of Aph. ovalisporum throughout the peninsula is considered invasion since a solid reference for its presence and bloom prior to the current reports is missing.

While field studies on the adaptation of the European species and their invasive potential are very scarce, laboratory studies with isolated strains have demonstrated that some invasive species have strong competitive abilities under changing scenarios. Mehnert et al. (2010) compared several "native" strains with "invasive" species and found that under low temperature, native species showed a higher growth rate than the invasive ones. However, under higher temperatures, the trend was the opposite and invasive strains performed better. Using these data, the authors, in a modeling effort, demonstrated that under a scenario of climate change with an increase of $4^{\circ} \mathrm{C}$ in the water temperature, the invasive species $C$. raciborskii would outcompete the native species (Aph. gracile) and that the potentially invasive Aph. ovalisporum would be an important component in the community (Mehnert et al., 2010). Although akinete production and overwintering/seeding play an important role in the life cycle of Nostocales, it is not necessarily the only mechanism for seeding; for example Aphanizomenon can seed from vegetative cells and filaments overwintering under ice (Grossart HP, personal communication). Temperature-dependent release of cylindrospermopsin was reported for Aph. ovalisporum, implicating management complications associated with global change scenarios (Cirés et al., 2011).

\section{MIDDLE EAST}

An exceptional bloom of Aph. ovalisporum first appeared in Lake Kinneret (Sea of Galilee), Israel in July 1994 and dominated the summer phytoplankton population for a few weeks (Pollingher et al., 1998). This toxic species (a producer of cylindrospermopsin) remained a regular member of the summer phytoplankton community since then and variably contributes between 10 and $40 \%$ to the summer phytoplankton biomass (Zohary, 2004). The reason for Aph. ovalisporum's first appearance and its later establishment in Lake Kinneret was a subject for debate (Berman, 1997, 2001;
Berman and Shteinman, 1998; Gophen et al., 1999) but it is clear now that this species took advantage of a new set of conditions that were imposed by global and regional changes (Hadas et al., submitted). The origin of the Aph. ovalisporum strain that established in Lake Kinneret remained unclear. A long and detailed record of the phytoplankton population in Lake Kinneret (since 1964) clearly shows its absence, although its presence at a level which is below the detection limit cannot be excluded. Interestingly, the Aph. ovalisporum strain isolated from Lake Kinneret was genotypically related to strains of Anabaena bergii isolated from constructed man-made lakes in Queensland, Australia (Shaw et al., 1999). Nevertheless, Anabaena bergii was not reported to bloom in the lake. The invasion process was repeated once again in Lake Kinneret as C. rasiborskii was first reported in 2000 as a minor component of the summer phytoplankton community but dominated the community in summer 2005 with biomass as high as $68 \mathrm{~g}(\mathrm{ww}) \mathrm{m}^{-2}$ (Hadas et al., submitted). Again, it is rather difficult to trace the origin of Lake Kinneret C. raciborskii but the fact that it is a non-cylindrospermopsin producing strain suggests that it may be related to European strains. These isolates do not produce cylindrospermopsin as opposed to Australian strains known to produce cylindrospermopsin and to Brazilian strains that have been reported to produce paralytic shellfish poisoning toxins (Neilan et al., 2003).

Other reports on Nostocales species in the Middle East include the Caspian Sea and Egypt. C. raciborskii was reported as a dominant phytoplankton species in the open and freshwater basin in the west part of the Anzali Lagoon (Caspian Sea, Iran). It was also dominant for short periods after flooding events in rivers flowing into the lagoon (Ramezanpoor, 2004). Toxic C. raciborskii and Raphidiopsis mediterranea were reported in an Egyptian shallow (4 $\mathrm{m}$ depth) freshwater El-Dowyrat fish pond for the first time in 2002. Human activities at the end of 2001, including removal of trees and elimination of macrophytes around the fish pond have led to an increase in temperature at the surface waters of the pond $\left(25-30^{\circ} \mathrm{C}\right)$. Both species showed seasonal variations with highest densities recorded in August each year (Mohamed, 2007). The loss of macrophytes was reported as one of the variables promoting the proliferation of C. raciborskii also in New Zealand lakes (Ryan et al., 2003). Thus local maintenance activities may be involved in an increase in temperature of the water column of temperate lakes and expand the distribution of C. raciborskii (Briand et al., 2004).

\section{NORTH AND SOUTH AMERICA}

The record of C. raciboskii-like Nostocales in North America goes back to 1955 when Anabaenopsis seriata Prescott, was reported from Kansas. Other reports of morphologically similar species originated from Minneapolis and Lake Erie (Kling, 2009). It was only in the 1990s when C. raciborskii was identified in many Florida lakes and rivers (Chapman and Schelske, 1997). Since then, C. raciborskii has been found in many water bodies of the central and eastern United States (Kling, 2009) including in many lakes and reservoirs in Indiana (Jones and Sauter, 2005). These sites tended to be shallow and turbid with high epilimnetic phosphorus and high chlorophyll $a$ values (Jones and Sauter, 2005). In 2004, C. raciborskii was identified in water samples from the Assiniboine River, Manitoba Canada. Variable morphological features 
were reported in accordance with earlier reports from Europe, and predictions based on the adaptability of that species to eutrophic conditions, elevated temperatures and turbid waters suggested its expansion in Lake Winnipeg and replacing the original phytoplankton assemblage (Leavitt et al., 2006; Patoine et al., 2006). Indeed summer blooms development and phytoplankton succession was recently reported. Lake Winnipeg shows reduced taxonomic diversity and an increased predominance of nitrogen-fixing cyanobacteria (Kling et al., 2011).

In South America C. raciborskii is well known in tropical waters of Brazil (Huszar et al., 2000), although the information about its distribution in southern latitudes is disperse and incomplete (Komárek, 2002). Vidal and Kruk (2008) analyzed spatial distribution and relative frequency of C. raciborskii in southern Uruguay, probably its southernmost distribution. C. raciborskii was found in several polymictic shallow eutrophic lakes as a dominant summer population and variable morphology. It was suggested higher occurrence of $C$. raciborskii in that climatic zone was associated with shallow, well-mixed eutrophic systems. Furthermore, morphological variations in C. raciborskii were not associated with latitudinal, continental, or even country distribution and independent of climatic origin.

\section{THE INVASION PROCESS}

Successful biological invasions involve complex interactions between the invading species and the physical and biological characteristics of the recipient environment. Often, invasive cyanobacteria species owe their success in colonizing new ecosystems to unique physiological characteristics (Figure 2). The invasion may be initiated with dispersion to new zones and is facilitated by

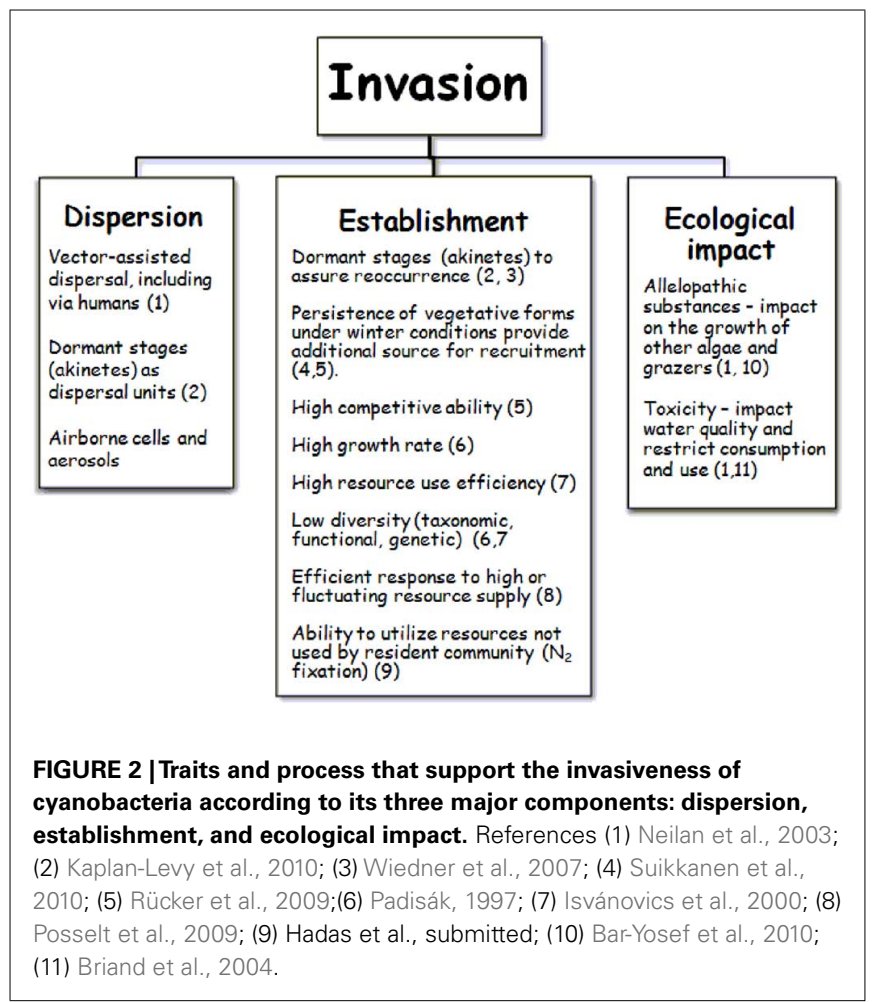

human activities by migrating animals or birds or by winds. Obviously, aeolian transport is an efficient means to transfer free-living microorganisms, prokaryotes, and protists (Smith et al., 2011). But reaching a new environment is not sufficient and the invader needs a variety of traits that support its establishment and proliferation. Two distinctive traits of Nostocalesa are: (1) The ability to form dormant cells (akinetes) that may survive long and extreme dispersion routes, on one hand and serve as overwintering form that survive unfavorable conditions and assure perennial germination and proliferation, on the other hand. (2) The ability to fix atmospheric nitrogen in the absence of combined inorganic sources. This last trait opens invasion opportunities for Nostocales in oligotrophic aquatic ecosystems, besides ecosystems temporarily limited in combined nitrogen and extends the spectrum of ecosystems to which they can invade.

Invasive cyanobacteria have growth rates that are relatively high compared with those of native species (Isvánovics et al., 2000). They may have high resource use efficiency or possess traits allowing them to gain access to resources unavailable to other species, such as the capacity to fix molecular nitrogen. C. raciborskii has high competitiveness under fluctuating nitrogen availability due to efficient uptake capacity for ammonium (Figueredo et al., 2007) and it also can fix atmospheric nitrogen, which allows it to escape $\mathrm{N}$ limitation (Briand et al., 2004; Moisander et al., 2011). This species may also utilize other limiting resources, such as phosphorus, more efficiently than other cyanobacteria due to high affinity and P storage capacity (Isvánovics et al., 2000; Wu et al., 2011) and, thus, be a superior nutrient competitor. Padisák (1997) suggested that $C$. raciborskii, tends to invade lakes with very high nutrient concentrations and low phytoplankton diversity, in addition to its ability to form akinetes allowing easy dispersal and environmental resistance. An important feature of Cylindrospermopsis is its wide thermal tolerance (Briand et al., 2004), which is essential to maintain the populations during cold winters. Detailed information on the effect of temperature on Nostocales life cycle processes such as akinete formation, their survival and germination, and the recruitment of vegetative filaments is currently scarce, but Cirés (2012) indicated that akinetes production of Aph. ovalisporum is rather restricted to a relative narrow temperature range. Padisák (1997) reported that akinetes of $C$. raciborskii germinate at temperatures $<24^{\circ} \mathrm{C}$. Further elucidation of life cycle processes responding to temperature is required in order to determine the invasiveness capabilities and limitations of various Nostocales species.

In many cases, floating Nostocales populations create a thick scum that blocks light penetration through the water column and inhibits the growth of other species, thus under high cyanobacterial growth, the populations remain established for longer periods minimizing competition by other algal groups. A scum formation is a dynamic process that depends on a delicate balance between flotation, cellular ballast and water turbulence (Calandrino and Paerl, 2011). Filaments floating at the water surface gain advantage over sub-surface phytoplankton populations. They directly intercept $\mathrm{CO}_{2}$ diffusing into the water from the atmosphere, thus minimizing inorganic carbon limitation of photosynthetic growth. Buoyant species contain UV-absorbing compounds such as mycosporine-like amino acids (MAAs) and scytonemin that ensure survival under extremely high irradiance conditions (Paerl 
and Paul, 2011). However, in some occasions scum formation represents a trap for the organisms that lose their dynamic buoyancy behavior and they are exposed to full sunshine (including high UV radiation in summer), as well as to nutrient deprivation. Frequently they die and remain on the water body shores with extremely low metabolic activities (i.e., $\mathrm{C}$ and $\mathrm{N}$ uptake, Oliver and Ganf, 2000 and references therein).

Another trait commonly found among Nostocales but also in other cyanobacteria (i.e., Microcystis) is the ability to synthesize a suite of secondary metabolites some of which were identified toxic to humans and animals (Stewart et al., 2011) and others may affect community structure functioning as allelo-chemicals that inhibit other phytoplankton species or deter and reduce grazing (Fastner et al., 2007; Paerl et al., 2011). Allelopathy was suggested as a beneficial trait of $C$. raciborskii that contributes to its stable dominance and geographic expansion (Figueredo et al., 2007) but also for other cyanobacteria species (Kaplan et al., in review). A unique feature of Aph. ovalisporum to acquire phosphate under oligotrophic conditions was recently reported by BarYosef et al. (2010). Excreted chemicals including the toxin cylindrospermopsin cause cells of some other phytoplankton species to make extracellular alkaline phosphatase whose inorganic phosphate product can be used by Aph. ovalisporum due to its high affinity to phosphate, thus contributing to its proliferation and domination. Aph. ovalisporum has been also found to outcompete other cyanobacteria at high temperatures due to higher growth rates than other Nostocales under these circumstances (Mehnert et al., 2010; Cirés et al., 2011).

In an attempt to follow the invasion route of $C$. raciborskii to new ecosystems Neilan et al. (2003) studied genetic variations between strains isolated from freshwater rivers and reservoirs in Australia, Brazil, Germany, Hungary, Portugal, and the USA by characterizing their 16S rRNA gene nucleotide sequences and by analyzing cyanobacterium-specific short tandem repeat sequence (HIP1). Three distinct groups of C. raciborskii strains were clustered: (1) a group consisting of strains from the USA and Brazil; (2) a group comprised of European strains (Germany, Hungary, and Portugal); (3) a group of strains from Australia. A subsequent study that examined other isolates of C. raciborskii revealed the same continental cluster distribution based on the 16S-23S internally transcribed spacer (ITS1) sequences (Gugger et al., 2005). This study suggests that the current expansion of C. raciborskii in Europe and in Central - and North America did not result from recent invasion and colonization by African or Australian strains (Padisák, 1997) but rather represent local strains that maintained "cryptic" populations over time and only recently proliferated due to climate change and variations in other environmental conditions. In a recent study, Piccini et al. (2011) proposed that phenotypic and genetic variability of $C$. raciborskii populations is linked to the existence of different ecotypes whose success is subject to the local environmental conditions.

Nevertheless, analysis of the 16S rRNA gene nucleotide sequences revealed $99.1 \%$ similarity between the strains of $C$. raciborskii collected from a range of global locations and continental clustering was not supported by statistically significant bootstrap values (Neilan et al., 2003). Therefore it cannot be excluded that $C$. raciborskii was transferred from the Australasian region to Europe unintentionally by humans or by migrating birds, thus providing the source of this cyanobacterium which is now reported in many previously unaffected temperate and subtropical water bodies. It is further speculated that some physiological characteristics unique to C. raciborskii support its proliferation in newly invaded ecosystems as they are currently exposed to higher temperature and environmental perturbations.

\section{GLOBAL VERSUS REGIONAL DRIVING FORCES}

In order to exploit its wide spectrum of physiological traits and to successfully outcompete native species, the conditions in a new habitat have to fit the invader's needs. Increased water temperatures, mostly during the summer, in subtropical, and temperate zones, is considered one of the major factors supported the invasion of C. raciborskii and other Nostocales (Figure 2). (Padisák, 1997; Briand et al., 2004; Rücker et al., 2009). Both C. raciborskii and Aph. ovalisporum are known to proliferate at temperatures higher than $20^{\circ} \mathrm{C}$ (Hadas et al., 1999, 2002; Mehnert et al., 2010), thus moderate elevation in water temperatures may open new ecological habitats for them. The persistence of Nostocales in their new locations is further maintained by their ability to form dormant cells, akinetes, which stay dormant but viable in the sediment for extended periods of time (Hense and Beckmann, 2006; KaplanLevy et al., 2010). This seed bank may reside in the sediment and wait for a warm summer to germinate. Consequently, bloom events may follow local climatic patterns. It is important to note that freshly settled akinetes are more likely to germinate during the next summer relative to those settled in earlier blooms as the latter are already covered deeper in the sediments and probably have lower germination potency.

Nostocales species are recently reported to reside in, and dominate eutrophic as well as oligotrophic aquatic systems (Figure 3). Eutrophic conditions provide ample nutrients that can be easily and competitively utilized by opportunistic invaders (Piehler et al., 2009). Such eutrophic systems maintain high internal nutrient recycling processes that fortify primary production and biomass accumulation. Although $\mathrm{N}_{2}$ fixation is commonly recorded during Nostocales blooms in eutrophic aquatic systems (mainly indicated by the presence of heterocysts, specialized cells formed under $\mathrm{N}$ limiting conditions), this process is responsible for up to $2 \%$ of $\mathrm{N}$ acquisition by the phytoplankton community (Ferber et al., 2004; Ariosa et al., 2006). The ability of many Nostocales to efficiently use low light, allows their growth in turbid waters as well as at high biomass concentrations.

Regional inappropriate management of watersheds and high pollution impact induce eutrophication, and are certainly involved in the Nostocales geographic expansion. But these invading species can survive and propagate also under oligotrophic conditions (Figure 3). This is achieved due to their various efficient phosphate acquisition capabilities (Isvánovics et al., 2000; Spróber et al., 2003; Posselt et al., 2009; Bar-Yosef et al., 2010) and nitrogen fixation which seems to be more relevant under oligotrophic than under eutrophic conditions. Thus, in oligotrophic systems, nitrogen cannot be considered as a limiting factor. Phosphate availability controls the development of the $\mathrm{N}_{2}$ fixing population and its growth. Consequently, management efforts to control 


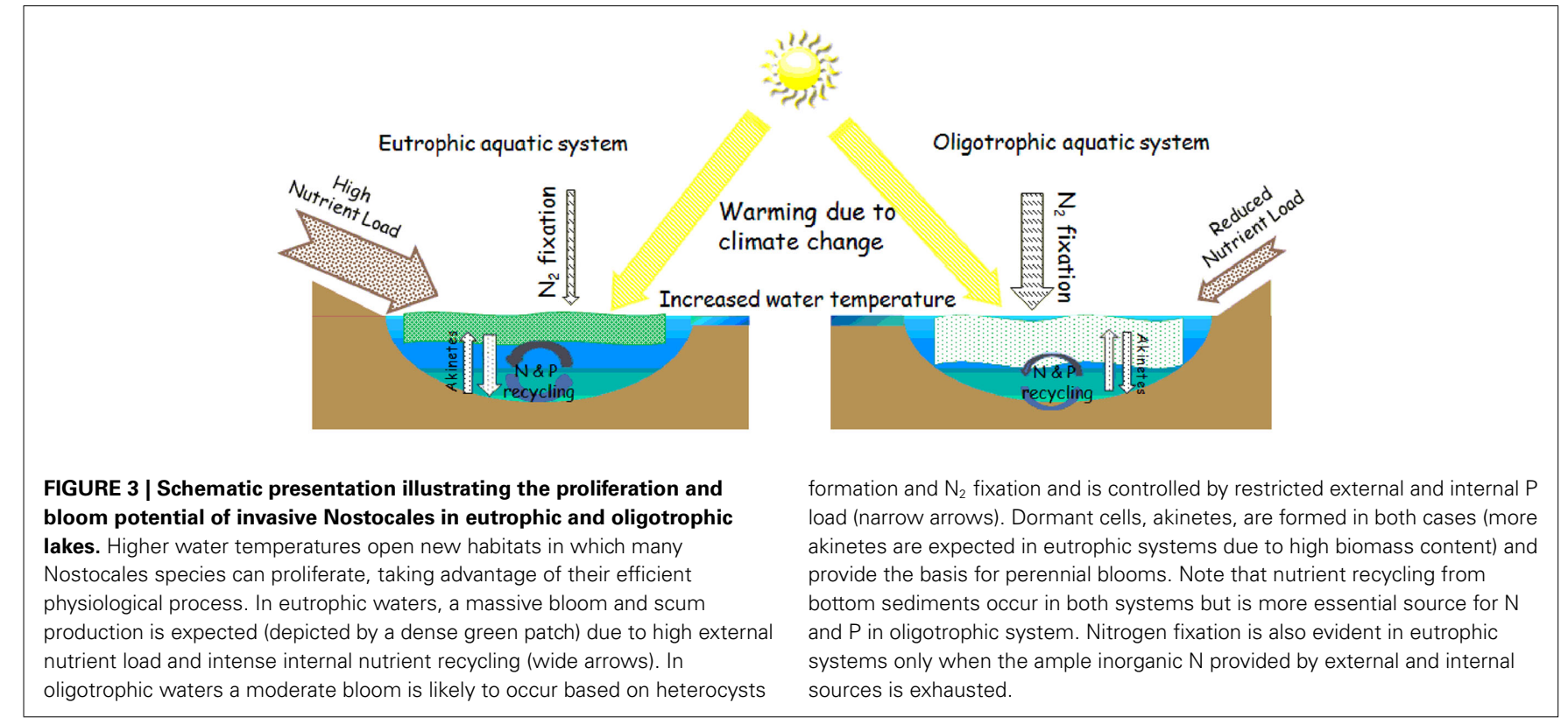

eutrophication by reducing $\mathrm{N}$ loads, apparently effective in reducing blooms of Microcystis and other Chroococcales species, may actually support the growth of Nostocales which easily outcompete native species in such $\mathrm{N}$ limited ecosystems (Schindler et al., 2008).

\section{CONSEQUENCES OF NOSTOCALES INVASIONS}

The immediate consequence of Nostocales invasion, besides the ecological impairment, is the expansion of toxic blooms as various strains produce harmful substances. Many Aph. ovalisporum and $C$. raciborskii strains produce the cytotoxic compound cylindrospermopsin whereas several Brazilian C. raciborskii strains have been reported to produce paralytic shellfish poisoning toxins: neosaxitoxin, saxitoxin, and gonyautoxins (Lagos et al., 1999). Interestingly, many strains isolated from temperate lakes in Europe and Northern America did not produce any known toxin, although they were found toxic in various bioassay experiments (Saker et al., 2004). Recent studies indicated that a given population may be composed of toxic and non-toxic strains (Ballot et al., 2011). The bloom of toxic Nostocales presents an immediate threat to human and animals that use the water for drinking, bathing and recreational activities (Carmichael, 2001). Local and governmental authorities are requested to provide solutions to minimize and control the bloom events by taking scientifically based management measures that should include consideration of the invasiveness of this cyanobacterial group under a scenario of global change (Jones and Sauter, 2005; Schindler et al., 2008).

The domination of recently invaded Nostocales affects the entire ecosystem as native phytoplankton species become rare and displaced and higher trophic levels may be affected via their toxins or due to loss of essential components of their food chain. C. raciborskii is known to affect the growth, reproduction and feeding of zooplankton (Leonard and Paerl, 2005) and cylindrospermopsin was shown to be accumulated in fish and in freshwater mussels (Saker and Eaglesham, 1999; Saker et al., 2004).

\section{PROSPECTIVE AND PREDICTIONS}

The current trend of increasing bloom events of cyanobacteria, including Nostocales, will probably be further enhanced as global warming continues. Any further temperature increase would promote the growth and development of Nostocales species in general, and that of the invasive species in particular, and would enable further expansion in the temperate zone (Mehnert et al., 2010). This trend was further confirmed by a coupled biological-physical model that predicted that high temperatures favor cyanobacteria over other phytoplankton taxa through increased growth rates that boost the development of blooms (Juehnk et al., 2011). A similar conclusion was reached by Wiedner et al. (2007) who evaluated a case of an earlier rise in water temperature associated with climate change. They suggested that such a scenario will prompt further spread of $C$. raciborskii to the temperate zone as earlier warming permits earlier germination, thereby shifting the pelagic populations to conditions which advance population establishment and growth. However, these models do not consider the ecological variations expected after this earlier germination, as different grazing pressure due to different grazer population (e.g., Winder and Schindler, 2004) or nutrient depletion that may follow an early bloom. These ecological variations are hard to predict and should be further investigated to improve models prediction.

While the possibilities to control and reduce the current trend of global climate change are rather limited, the management of eutrophication processes is feasible. Since a synergistic effect of nutrients and climate was frequently indicated in many sites invaded by Nostocales, it is important that nutrient concentrations in many temperate and subtropical lakes be reduced substantially from present values if cyanobacterial dominance is to be controlled (Kosten et al., 2012). Based on long term experimental manipulation, Schindler et al. (2008) concluded that N-fixing cyanobacteria 
cannot be limited by a shortage of dissolved $\mathrm{N}$ and instead are competitively favored. Thus reducing $\mathrm{N}$ inputs could actually intensify the dominance of $\mathrm{N}$-fixing cyanobacteria thus enhancing the expansion of invasive Nostocales. The alternative approach to control and reduce blooms of invasive Nostocales species and their further expansion is to control and reduce external and internal sources of phosphorus, a complex task by itself.

\section{REFERENCES}

Ariosa, Y., Carrasco, D., Quesada, A., and Eduardo, F.-V. (2006). Incorporation of different $\mathrm{N}$ sources and light response curves of nitrogenase and photosynthesis by cyanobacterial blooms from rice fields. Microb. Ecol. 51, 394-403.

Ballot, A., Ramm, J., Rundberget, T., Kaplan-Levy, R. N., Hadas, O., Sukenik, A., and Wiedner, C. (2011). Occurrence of noncylindrospermopsin-producing Aphanizomenon ovalisporum and Anabaena bergii in Lake Kinneret (Israel). J. Plankton Res. 33, 1736-1746.

Bar-Yosef, Y., Sukenik, A., Hadas, O., Viner-Mozzini, Y., and Kaplan, A. (2010). Enslavement in the water body by toxic Aphanizomenon ovalisporum, inducing alkaline phosphatase in phytoplanktons. Curr. Biol. 20, 1557-1561.

Bazzichelli, G., and Abdelahad, N. (1994). Caractérisation morphométrique et statistique de deux populations d'Aphanizomenon du groupe Aphanizomenon ovalisporum Forti des lacs de Nemi et Albano (Italie). Algological Studies/Archiv für Hydrobiologie 73(Suppl.), 1-21.

Berman, T. (1997). Dissolved organic nitrogen utilization by an Aphanizomenon bloom in Lake Kinneret. J. Plankton Res. 19, 577-586.

Berman, T. (2001). The role of DON and the effect of N:P ratios on occurrence of cyanobacterial blooms: implications from the outgrowth of Aphanizomenon in Lake Kinneret. Limnol. Oceanogr. 46, 443-447.

Berman, T., and Shteinman, B. (1998). Phytoplankton development and turbulent mixing in Lake Kinneret (1992-1996). J. Plankton Res. 20, 709-726.

Bouvy, M., Falcão, D., Marinho, M., Pagano, M., and Moura, A. (2000). Occurrence of Cylindrospermopsis (Cyanobacteria) in 39 Brazilian tropical reservoirs during the 1998 drought. Aquat. Microb. Ecol. 23, $13-27$.

Briand, J.-F., Leboulanger, C., Humbert, J.-F., Bernard, C., and Dufour, P. (2004). Cylindrospermopsis raciborskii (cyanobacteria) invasion at mid-latitudes: selection, wide physiological tolerance, or global warming? J. Phycol. 40, 231-238.

Calandrino, E. S., and Paerl, H. W. (2011). Determining the potential for the proliferation of the harmful cyanobacterium Cylindrospermopsis raciborskii in Currituck Sound, North Carolina. Harmful Algae 11, 1-9.

Carmichael, W. W. (2001). Health effects of toxin-producing cyanobacteria: "the CyanoHABs." Hum. Ecol. Risk Assess. 7, 1393-1407. Chapman, A. D., and Schelske, C. L. (1997). Recent appearance of Cylindrospermopsis (Cyanobacteria) in five hypertrophic Florida Lakes. J. Phycol. 33, 191-195.

Chonudomkul, D., Yongmanitchai, W., Theeragool, G., Kawachi, M., Kasai, F., Kaya, K., and Watanabe, M. M. (2004). Morphology, genetic diversity, temperature tolerance and toxicity of Cylindrospermopsis raciborskii (Nostocales, Cyanobacteria) strains from Thailand and Japan. FEMS Microbiol. Ecol. 48, 345-355.

Cirés, S. (2012). Ecophysiology, Annual Life-Cycles and Cyanotoxin Production of Planktonic Cyanobacteria Anabaena, Aphanizomenon and Microcystis in Spanish Freshwater Reservoirs. Ph.D. thesis, Universidad Autónoma de Madrid, Madrid.

Cirés, S., Wörmer, L., Timón, J., Wiedner, C., and Quesada, A. (2011). Cylindrospermopsin production and release by the potentially invasive cyanobacterium Aphanizomenon ovalisporum under temperature and light gradients. Harmful Algae 10, 668-675.

Colautti, R. I., and Macisaac, H. J. (2004). A neutral terminology to define "invasive" species. Divers. Distrib. 10, 135-141.

Dobberfuhl, D. R. (2003). Cylindrospermopsis raciborskii in three central Florida lakes: population dynamics, controls, and management implications. Lake Reserv. Manag. 19, 341-348.

Dyble, J., Paerl, H. W., and Neilan, B. A. (2002). Genetic characterization of Cylindrospermopsis raciborskii

\section{ACKNOWLEDGMENTS}

This work was partly supported by the German Ministry of Research and Technology (BMBF) and Israel Ministry of Science and Technology (MOST) under contracts FKZ 02WT0985 and WR803. Assaf Sukenik and Ora Hadas acknowledge the continuous support of the Israel Water Authority provided to the Kinneret Limnological Laboratory, IOLR.

(Cyanobacteria) isolates from diverse geographic origins based on nifH and cPcBA-IGS nucleotide sequence analysis. Appl. Environ. Microbiol. 68, 2567-2571.

Elton, C. S. (1958). The Ecology of Invasions by Animals and Plants. London: Methuen.

Fastner, J., Rücker, J., Stüken, A., Preußel, K., Nixdorf, B., Chorus, I., Köhler, A., and Wiedner, C. (2007). Occurrence of the cyanobacterial toxin cylindrospermopsin in northeast Germany. Environ. Toxicol. 22, 26-32.

Ferber, L. R., Levine, S. N., Lini, A., and Livingston, G. P. (2004). Do cyanobacteria dominate in eutrophic lakes because they fix atmospheric nitrogen? Freshw. Biol. 49, 690-708.

Figueredo, C. C., Giani, A., and Bird, D. F. (2007). Does allelopathy contribute to Cylindrospermopsis raciborskii (cyanobacteria) bloom occurrence and geographic expansion? J. Phycol. 43, 256-265.

Gophen, M., Smith, V. H., Nishri, A., and Threlkeld, S. T. (1999). Nitrogen deficiency, phosphorus sufficiency, and the invasion of Lake Kinneret, Israel, by the N2-fixing cyanobacterium Aphanizomenon ovalisporum. Aquat. Sci. 61, 293-306.

Gugger, M., Molica, R., Le Berre, B., Dufour, P., Bernard, C., and Humbert, J.-F. (2005). Genetic diversity of Cylindrospermopsis strains (Cyanobacteria) isolated from four continents. Appl. Environ. Microbiol. 71, 1097-1100.

Hadas, O., Pinkas, R., Delphine, E. Vardi, A., Kaplan, A., and Sukenik, A. (1999). Limnological and ecophysiological aspects of Aphanizomenon ovalisporum bloom in Lake Kinneret, Israel. J. Plankton Res. 21, 1439-1453.

Hadas, O., Pinkas, R., MalinskyRushansky, N., Shalev-Alon, G., Delphine, E., Berner, T., Sukenik, A., and Kaplan, A. (2002). Physiological variables determined under laboratory conditions may explain the bloom of Aphanizomenon ovalisporum in Lake Kinneret. Eur. J. Phycol. 37, 259-267.
Hense, I., and Beckmann, A. (2006). Towards a model of cyanobacteria life cycle - effects of growing and resting stages on bloom formation of N2-fixing species. Ecol. Modell. 195, 205-218.

Huszar, V. L. M., Silva, L. H. S., Marinho, M., Domingos, P., and Sant'anna, C. L. (2000). Cyanoprokaryote assemblages in eight productive tropical Brazilian waters. Hydrobiologia 424, 67-77.

Isvánovics, V., Shafik, H. M., Présing, M., and Juhos, S. (2000). Growth and phosphate uptake kinetics of the cyanobacterium, Cylindrospermopsis raciborskii (Cyanophyceae) in throughflow cultures. Freshw. Biol. 43, 257-275.

Jones, W. W., and Sauter, S. (2005). Distribution and abundance of Cylindrospermopsis raciborskii in Indiana lakes and reservoirs. Schoool of Public and Environmental Affairs, Indiana University. Available al: http://www.spea. indiana.edu/clp/finalcylindro $\% 20$ web.pdf

Juehnk, K. D., Brueggemann, R., Rücker, J., Luther, B., Simon, U., Nixdorf, B., and Wiedner, C. (2011). Modelling life cycle and population dynamics of Nostocales (cyanobacteria). Environ. Modell. Softw. 26, 669-677.

Kaplan-Levy, R. N., Hadas, O., Summers, M. L., Rücker, J., and Sukenik, A. (2010). "Akinetes - dormant cells of cyanobacteria," in Dormancy of Cells and Organisms, eds J. Cerdà, M. Clark, and E. Lubzens (Berlin: Springer), 269-300.

Kaštovský, J., Hauer, T., Mareš, J., Krautová, M., Bešta, T., Komárek, J., Desortová, B., Heteša, J., Hindáková, A., Houk, V., Janeček, E., Kopp, R., Marvan, P., Pumann, P., Skácelová, O., and Zapomělová, E. (2011). A review of the alien and expansive species of freshwater cyanobacteria and algae in the Czech Republic. Biol. Invasions 12, 3599-3625.

Kling, H. (2009). Cylindrospermopsis raciborskii (Nostocales, Cyanobacteria): a brief historic overview and recent discovery in the Assiniboine River (Canada). Fottea 9, 45-47.

Kling, H. J., Watson, S. B., Mccullough, G. K., and Stainton, M. P. 
(2011). Bloom development and phytoplankton succession in Lake Winnipeg: a comparison of historical records with recent data. Aquat. Ecosystems Health Manag. 14, 219-224.

Kokociński, M., Dziga, D., Spoof, L., Stefaniak, K., Jurczak, T., MankiewiczBoczek, J., and Meriluoto, J. (2009). First report of the cyanobacterial toxin cylindrospermopsin in the shallow, eutrophic lakes of western Poland. Chemosphere 74, 669-675.

Komárek, J. (2002). "Problems in cyanobacterial taxonomy: implications for most common toxin producing species," in Workshop Freshwater Harmful Algal Blooms: Health Risk and Control Management, eds S. Melchiorre, E. Viaggiu, and M. Bruno (Rapporti ISTISAN: Rome), 6-43.

Komárek, J., and Komárkova, J. (2003). Phenotype diversity of the cyanoprokaryotic genus Cylindrospermopsis (Nostocales); review 2002. Fottea (Praha) 3, 1-30.

Kosten, S., Huszar, V. L. M., Bécares, E., Costa, L. S., Van Donk, E., Hansson, L.-A., Jeppesen, E., Kruk, C., Lacerot, G., Mazzeo, N., De Meester, L., Moss, B., Lürling, M., Nõges, T., Romo, S., and Scheffer, M. (2012). Warmer climates boost cyanobacterial dominance in shallow lakes. Glob. Chang. Biol. 18, 118-126.

Lagos, N., Onodera, H., Zagatto, P. A., Andrinolo, D., Azevedo, S. M. F. Q., and Oshima, Y. (1999). The first evidence of paralytic shellfish toxins in the freshwater cyanobacterium Cylindrospermopsis raciborskii, isolated from Brazil. Toxicon 37, 1359-1373.

Leavitt, P. R., Brock, C. S., Ebel, C., and Alain, P. (2006). Landscapescale effects of urban nitrogen on a chain of freshwater lakes in Central North America. Limnol. Oceanogr. 51, 2262-2277.

Leonard, J., and Paerl, H. (2005). Zooplankton community structure, micro-zooplankton grazing impact, and seston energy content in the St. Johns River system, Florida as influenced by the toxic cyanobacterium Cylindrospermopsis raciborskii. Hydrobiologia 537, 89-97.

Levine, J. M., Vilà, M., Antonio, C. M. D., Dukes, J. S., Grigulis, K., and Lavorel, S. (2003). Mechanisms underlying the impacts of exotic plant invasions. Proc. R. Soc. Lond. B Biol. Sci. 270, 775-781.

Litchman, E. (2010). Invisible invaders: non-pathogenic invasive microbes in aquatic and terrestrial ecosystems. Ecol. Lett. 13, 1560-1572.

Lockwood, J., Hoopes, M., and Marchetti, M. (2007). Invasion Ecology. Malden, MA: Blackwell Publishing.

Mehnert, G., Leunert, F., Cires, S., Johnk, K. D., Rucker, J., Nixdorf, B., and Wiedner, C. (2010). Competitiveness of invasive and native cyanobacteria from temperate freshwaters under various light and temperature conditions. J. Plankton Res. 32, 1009-1021.

Meinesz, A., Belsher, T., Thibaut, T., Antolic, B., Mustapha, K. B. Boudouresque, C.-F., Chiaverini, D., Cinelli, F., Cottalorda, J.-M., Djellouli, A., El Abed, A., Orestano, C., Grau, A. M., Ivesa, L., Jaklin, A., Langar, H., Massuti-Pascual, E., Peirano, A., Tunesi, L., De Vaugelas, J., Zavodnik, N., and Zuljevic, A. (2001). The introduced green alga Caulerpa taxifolia continues to spread in the Mediterranean. Biol. Invasions 3, 201-210.

Mohamed, Z. A. (2007). First report of toxic Cylindrospermopsis raciborskii and Raphidiopsis mediterranea (Cyanoprokaryota) in Egyptian fresh waters. FEMS Microbiol. Ecol. 59, 749-761.

Moisander, P. H., Cheshire, L. A., Braddy, J., Calandrino, E. S., Hoffman, M., Piehler, M. F., and Paerl, H. W. (2011). Facultative diazotrophy increases Cylindrospermopsis raciborskii competitiveness under fluctuating nitrogen availability. FEMS Microb. Ecol. 79, 800-811.

Molica, R., Onodera, H., García, C., Rivas, M., Andrinolo, D., Nascimento, S., Meguro, H., Oshima, Y., Azevedo, S., and Lagos, N. (2002). Toxins in the freshwater cyanobacterium Cylindrospermopsis raciborskii (Cyanophyceae) isolated from Tabocas reservoir in Caruaru, Brazil, including demonstration of a new saxitoxin analogue. Phycologia 41, 606-611.

Neilan, B. A., Saker, M. L., Fastner, J., Törökné, A., and Burns, B. P. (2003). Phylogeography of the invasive cyanobacterium Cylindrospermopsis raciborskii. Mol. Ecol. 12, 133-140.

Oliver, R., and Ganf, G. (2000). "Freshwater blooms," in The Ecology of Cyanobacteria, eds B. Whitton and M. Potts (Dordrecht: Kluwer Academic Publishers), 149-194.

Padisák, J. (1997). Cylindrospermopsis raciborskii (Woloszynska) Seenayya et Subba Raju, an expanding, highly adaptive cyanobacterium: worldwide distribution and review of its ecology. Archiv für Hydrobiologie 107, 563-593.

Paerl, H. W., Hall, N. S., and Calandrino, E. S. (2011). Controlling harmful cyanobacterial blooms in a world experiencing anthropogenic and climatic-induced change. Sci. Total Environ. 409, 1739-1745.

Paerl, H. W., and Paul, V. J. (2011). Climate change: links to global expansion of harmful cyanobacteria. Water Res. 46, 1349-1363.

Patoine, A., Graham, M. D., and Leavitt, P. R. (2006). Spatial variation of nitrogen fixation in lakes of the northern Great Plains. Limnol. Oceanogr. 51, 1665-1677.

Piccini, C., Aubriot, L., Fabre, A., Amaral, V., Gonzalez-Piana, M., Giani, A., Figueredo, C. C., Vidal, L., Kruk, C., and Bonilla, S. (2011). Genetic and eco-physiological differences of South American Cylindrospermopsis raciborskii isolates support the hypothesis of multiple ecotypes. Harmful Algae 10, 644-653.

Piehler, M. F., Dyble, J., Moisander, P. H., Chapman, A. D., Hendrickson, J., and Paerl, H. W. (2009). Interactions between nitrogen dynamics and the phytoplankton community in Lake George, Florida, USA. Lake Reserv. Manag. 25, 1-14.

Pimentel, D., Mcnair, S., Janecka, J., Wightman, J., Simmonds, C., O'connell, C., Wong, E., Russel, L., Zern, J., Aquino, T., and Tsomondo, T. (2001). Economic and environmental threats of alien plant, animal, and microbe invasions. Agriculture Ecosystems Environ. 84, 1-20.

Pollingher, U., Hadas, O., Yacobi, Y. Z. Zohary, T., and Berman, T. (1998). Aphanizomenon ovalisporum (Forti) in Lake Kinneret, Israel. J. Plankton Res. 20, 1321-1339.

Posselt, A. J., Burford, M. A., and Shaw, G. (2009). Pulses of phosphate promote dominance of the toxic cyanophyte Cylindrospermopsis raciborskii in a subtropical water reservoir. J. Phycol. 45, 540-546.

Quesada, A., Moreno, E., Carrasco, D., Paniagua, T., Wormer, L., Hoyos, C. D., and Sukenik, A. (2006). Toxicity of Aphanizomenon ovalisporum (Cyanobacteria) in a Spanish water reservoir. Eur. J. Phycol. 41, 39-45.

Ramezanpoor, Z. (2004). Ecological study of phytoplankton of the Anzali lagoon (N Iran) and its outflow into the Caspian Sea. Czech Phycol. Olomouc 4, 145-154.

Ricciardi, A., and Cohen, J. (2007). The invasiveness of an introduced species does not predict its impact. Biol. Invasions 9, 309-315.

Richardson, D. (ed.). (2011). Fifty Years of Invasion Ecology - The Legacy of Charles Elton Chichester. Oxford: Wiley-Blackwell.

Romo, S., and Miracle, M. R. (1994). Population dynamics and ecology of subdominant phytoplankton species in a shallow hypertrophic lake (Albufera of Valencia, Spain). Hydrobiologia 273, 37-56.

Rücker, J., Tingwey, E., Wiedner, C., Anu, C., and Nixdorf, B. (2009). Impact of the inoculum size on the population of Nostocales cyanobacteria in temperate lakes. J. Plankton Res. 31, 1151-1159.

Ryan, E. F., P, H. D., and Barnes, G. (2003). Recent occurrence of Cylindrospermopsis raciborskii in Waikato lakes of New Zealand. N. Z. J. Mar. Freshwater Res. 37, 829-836.

Saker, M. L., and Eaglesham, G. K. (1999). The accumulation of cylindrospermopsin from the cyanobacterium Cylindrospermopsis raciborskii in tissues of the redclaw crayfish Cherax quadricarinatus. Toxicon 37, 1065-1077.

Saker, M. L., Metcalf, J. S., Codd, G. A., and Vasconcelos, V. M. (2004). Accumulation and depuration of the cyanobacterial toxin cylindrospermopsin in the freshwater mussel Anodonta cygnea. Toxicon 43, 185-194.

Schindler, D. W., Hecky, R. E., Findlay, D. L., Stainton, M. P., Parker, B. R., Paterson, M. J., Beaty, K. G., Lyng, M., and Kasian, S. E. M. (2008). Eutrophication of lakes cannot be controlled by reducing nitrogen input: results of a $37-$ year whole-ecosystem experiment. Proc. Natl. Acad. Sci. U.S.A. 105, 11254-11258.

Shaw, G. R., Sukenik, A., Livne, A. Chiswell, R. K., Smith, M. J., Seawright, A. A., Norris, R. L., Eaglesham, G. K., and Moore, M. R. (1999). Blooms of the cylindrospermopsin containing cyanobacterium, Aphanizomenon ovalisporum (Forti), in newly constructed lakes, Queensland, Australia. Environ. Toxicol. 14, 167-177.

Smith, D. J., Griffin, D. W., and Jaffe, D. A. (2011). The high life: transport of microbes in the atmosphere. Eos Trans. 92, 249.

Sprőber, P., Shafik, H. M., Présing, M., Kovács, A. W., and Herodek, S. (2003). Nitrogen uptake and fixation in the cyanobacterium Cylindrospermopsis raciborskii under different nitrogen 
conditions. Hydrobiologia 506-509, 169-174.

Stewart, I., Carmichael, W. W., and Backer, L.C. (2011). "Toxic Cyanobacteria," in Water and Sanitation-Related Diseases and the Environment, ed. J. M. H. Selendy (John Wiley and Sons, Inc.), 95-110. Suikkanen, S., Kaartokallio, H., Hällfors, S., Huttunen, M., and Laamanen, M. (2010). Life cycle strategies of bloom-forming, filamentous cyanobacteria in the Baltic Sea. Deep Sea Res. Part 2 Top. Stud. Oceanogr. 57, 199-209.

Traveset, A., and Richardson, D. M. (2006). Biological invasions as disruptors of plant reproductive mutualisms. Trends Ecol. Evol. 21, 208-216.

Vidal, L., and Kruk, C. (2008). Cylindrospermopsis raciborskii
(Cyanobacteria) extends its distribution to Latitude $34\left(53^{\prime} \mathrm{S}\right.$ : taxonomical and ecological features in Uruguayan eutrophic lakes. Pan Am. J. Aquat. Sci. 3, 142-151.

Vitousek, P. M., Mooney, H. A., Lubchenco, J., and Melillo, J. M. (1997). Human domination of earth's ecosystems. Science 277, 494-499.

Wiedner, C., Rücker, J., Brüggemann, R., and Nixdorf, B. (2007). Climate change affects timing and size of populations of an invasive cyanobacterium in temperate regions. Oecologia 152, 473-484.

Winder, M., and Schindler, D. E. (2004). Climate change uncouples trophic interactions in a lake ecosystem. Ecology 85, 2100-2106.

Wood, S. A., and Stirling, D. J. (2003). First identification of the cylindrospermopsin-producing cyanobacterium Cylindrospermopsis raciborskii in New Zealand. N. Z. J. Mar. Freshwater Res. 37, 821-828.

Wu, Z., Zeng, B., Li, R., and Song, L. (2011). Physiological regulation of Cylindrospermopsis raciborskii (Nostocales, Cyanobacteria) in response to inorganic phosphorus limitation. Harmful Algae 15, 53-58.

Zohary, T. (2004). Changes to the phytoplankton assemblage of Lake Kinneret after decades of a predictable, repetitive pattern. Freshw. Biol. 49, 1355-1371.

Conflict of Interest Statement: The authors declare that the research was conducted in the absence of any commercial or financial relationships that could be construed as a potential conflict of interest.
Received: 11 January 2012; accepted: 20 February 2012; published online: 09 March 2012.

Citation: Sukenik A, Hadas O, Kaplan $A$ and Quesada A (2012) Invasion of Nostocales (cyanobacteria) to subtropical and temperate freshwater lakes physiological, regional, and global driving forces. Front. Microbio. 3:86. doi: 10.3389/fmicb.2012.00086

This article was submitted to Frontiers in Aquatic Microbiology, a specialty of Frontiers in Microbiology.

Copyright (ㄷ 2012 Sukenik, Hadas, Kaplan and Quesada. This is an openaccess article distributed under the term of the Creative Commons Attribution Non Commercial License, which permits non-commercial use, distribution, and reproduction in other forums, provided the original authors and source are credited. 